\title{
Distribution of Benthic Foraminifera in the Marine Estuary of the Guadalquivir River (SW Spain): A Preliminary Report
}

María Luz González-Regalado ${ }^{1}$, Berta Carro ${ }^{1}$, Marta Arroyo ${ }^{1}$, Francisco Ruiz ${ }^{1,3,7 *}$, José Borrego ${ }^{1}$, Manuel Abad ${ }^{2}$, Tatiana Izquierdo ${ }^{2}$, Josep Tosquella' ${ }^{1}$, María Isabel Prudencio ${ }^{3}$, María Isabel Dias ${ }^{3}$, Rosa Marques $^{3}$, Verónica Romero $^{1}$, Joaquín Rodríguez Vidal ${ }^{1,7}$, Luis Miguel Cáceres ${ }^{1,7}$, Paula Gómez ${ }^{1,7}$, Antonio Toscano ${ }^{1,7}$, Guadalupe Monge $^{4}$, María Isabel Carretero ${ }^{4}$, Juan Manuel Campos ${ }^{5,7}$, Javier Bermejo ${ }^{5,7}$ and Edith Xío Mara García ${ }^{6}$

${ }^{1}$ Departamento de Ciencias de la Tierra, Universidad de Huelva, Spain

${ }^{2}$ Universidad de Atacama, Chile

${ }^{3}$ Instituto Superior Técnico, Universidad de Lisboa, Portugal

${ }^{4}$ Departamento de Cristalografía, Universidad de Sevilla, Spain

${ }^{5}$ Departamento de Historia, Universidad de Huelva, Spain

${ }^{6}$ Centro Universitario de Tonalá, Universidad de Guadalajara, México

${ }^{7}$ Centro de Investigación en Patrimonio Histórico, Universidad de Huelva, Spain

Submission: February 09, 2019; Published: February 15, 2019

Corresponding author: Francisco Ruiz, Departamento de Ciencias de la Tierra, Universidad de Huelva, Instituto Superior Técnico, Universidad de Lisboa. Avda. Tres de Marzo, s/n; CP 21071-Huelva, Spain

\section{Abstract}

Three zones are differentiated in the marine sector of the Guadalquivir estuary (SW Spain), according to a multidisciplinary analysis (water, sediment, foraminifera). Both salinities and $\mathrm{pH}$ increase from the innermost areas (zone 1: Ammonia tepida) to the mouth (zone 3: Ammonia beccarii), with an intermediate zone 2 (Ammonia beccarii-Triloculina trigonula). Both density and diversity are low to very low, except near the transition between zones 2 and 3. Planktonic foraminifera decrease sea Ward from zone 1 to zone 3.

\section{Introduction}

Benthic foraminifera are among the main environmental markers in coastal areas. The distribution of these microorganisms is conditioned by diverse physical-chemical parameters of the waters (salinity, dissolved oxygen, $\mathrm{pH}$ ), as well as by the characteristics of the substrate where they live (granulometry, geochemistry) [1-3]. Its abundance and diversity can be altered by changes in the dynamics of the environment, erosion of the bottom or anthropic contamination, among other factors [4,5]. In southwestern Spain, several studies have analyzed the spatial distribution of benthic foraminifera in the different sedimentary environments of three estuaries (Guadiana, Piedras and Tinto-Odiel) [6-8].

In a synthetic way, the main species of each of them are the following:
a) High salt marsh: Trochammina inflata.
b) Low salt marsh: Entzia macrescens.

c) Channel margin: Ammonia inflata and Astrononion stelligerum.

d) Marine channel: Ammonia beccarii and Quinqueloculina spp.

In this short note, we present the first data about the benthic foraminifera of the Guadalquivir river (SW Spain). The data obtained are related to several parameters of both waters and sediments in which they have been found.

\section{Study Area}

The Guadalquivir river is the main fluvial stream of southwestern Spain $(657 \mathrm{~km})$. This river has a very irregular regime, with an annual average of $185 \mathrm{~m}^{3} \mathrm{~s}^{-1}$ and a maximum of more than $1,000 \mathrm{~m}^{3} \mathrm{~s}^{-1}[9,10]$. These flows are partially controlled by several dams located upstream. The tidal regime is mesotidal and semidiurnal, with an average tidal range of $3.6 \mathrm{~m}$ [11]. The marine estuary of the Guadalquivir River is constituted by the 
Doñana National Park (SW Spain), one of the most important wetlands in southwestern Europe (Figure 1: 54,215 ha). This Biosphere Reserve includes a rich variety of ecosystems (freshwater ponds, dunes, cheniers, sandy ridges), with a wide fluvio-tidal marshland $(27,000$ ha) drained by numerous ebbtide channels. This complex inner scenario is protected by the NW-SE elongated Doñana spit (Figure 1).

\section{Methods}

The field campaign was held in February 2017. The physicochemical variables of water $(\mathrm{pH}$, conductivity, redox potential and temperature) were determined in situ at three sampling points (Figure 1: A-B-C) by using portable multiparameter equipment (CrisonMM40). The electrodes were calibrated prior to sampling and tested between each sampling point. Conductivity was transformed to salinity in the following chapters, according to the data obtained in numerous points of the studied area [12]. Five sediment samples (Figure 1: 1-5) were obtained with a Van Veen grab. These samples were stored in labeled self-sealing plastic bags until further analysis in the laboratory at $4{ }^{\circ} \mathrm{C}$ until they reached the laboratory, where they were dried in an oven at $60^{\circ} \mathrm{C}$ until constant weight was reached. The particle-size distribution of the collected sediments was studied using a Malvern Mastersizer 2000 (Malvern Instruments Ltd., UK) belonging to the Department of Earth Sciences (University of Huelva, Spain). Five sediment subsamples were separated for micropaleontological analysis. Forty grams of sediment were wet sieved through a $63 \mu \mathrm{m}$ mesh sieve and the residue was dried in an oven at $70{ }^{\circ} \mathrm{C}$. All foraminifera were picked from each subsample, with the calculation of the percentages of both the benthic foraminiferal species and the planktonic/ benthic index $(\mathrm{P} / \mathrm{B}$, in \%).

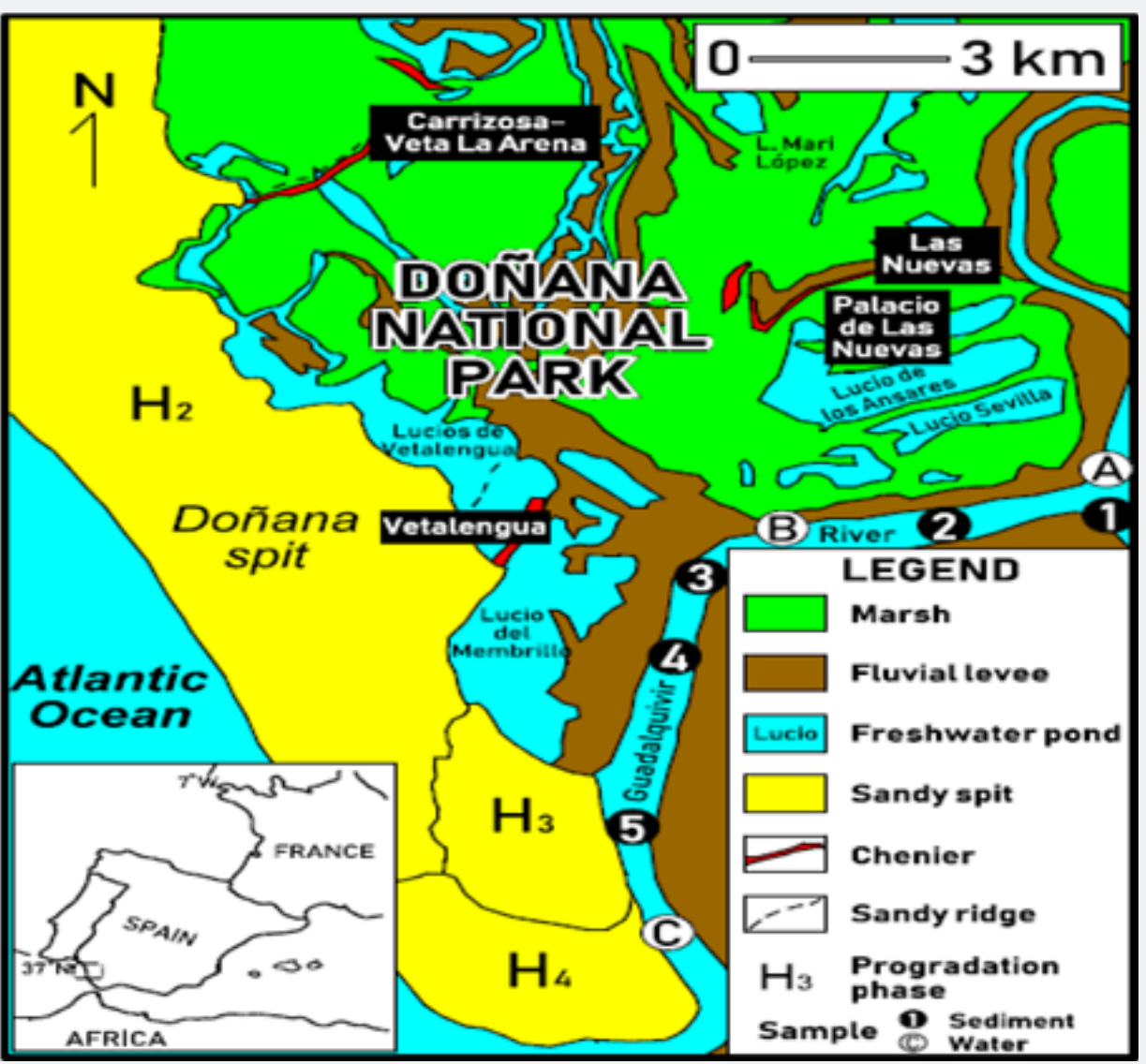

Figure 1: Marine sector of the Guadalquivir river estuary: main geomorphological features and location of both water and sediment samples.

\section{Results and Discussion}

\section{Waters and sediments}

In winter, conductivity values of this marine estuary are low to very low, increasing from the most internal areas $(1,817 \mu \mathrm{S}$; salinity <1o/oo $)$ to the mouth $(7,624 \mu \mathrm{S}$; salinity: $3.50 / 00-6.4$ $0 / 00)$. These data coincide with those provided by previous research $\left(<5^{\circ} / 00\right)$ [13]. These waters are alkaline, with a rising $\mathrm{pH}$ towards the sea (7.31-7.88). Eh (85.3-93.4 $\mathrm{mV}$ ) and temperature $\left(13^{\circ} \mathrm{C}-14.6^{\circ} \mathrm{C}\right)$ increase in the same direction. Bottom sediments of the innermost zone present similar percentages of sand and silt (Figure 2: sample 1). Near the mouth, bioclastic sands are dominant, with numerous fragments of molluscs, bryozoans and echinoid spines, among others. Silt can become dominant in some cases, coinciding with lower flow rates (Figure 2: sample 3) (Figure 2) 


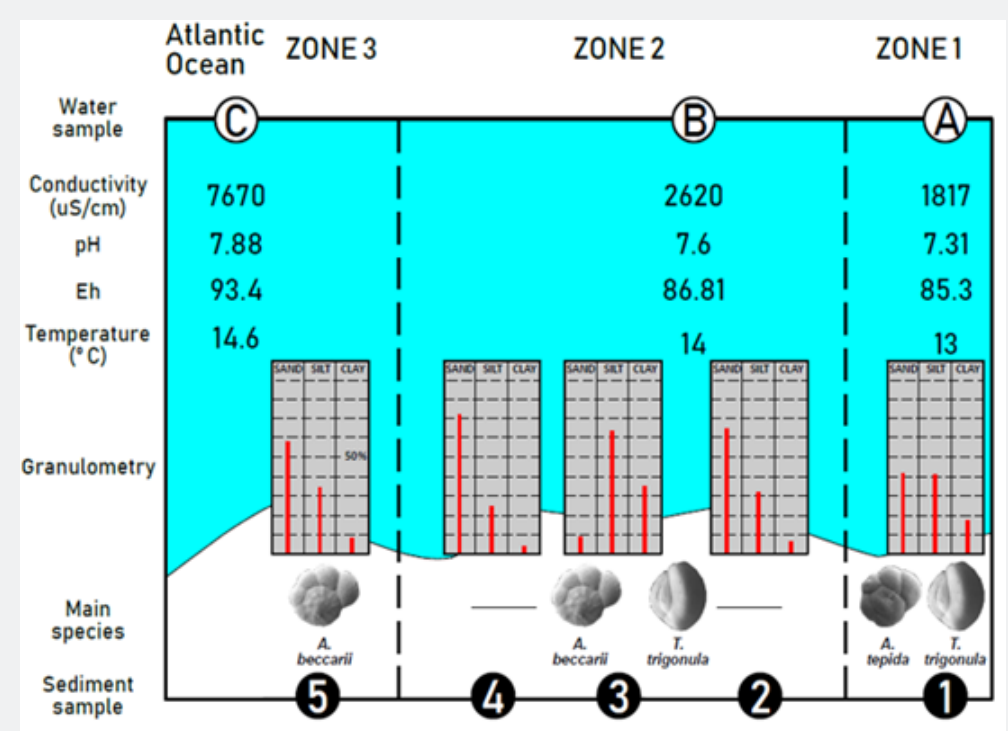

Figure 2: Zonation of the area studied, according to the water parameters, granulometry and foraminiferal distribution.

\section{Benthic foraminifera: abundance and diversity}

A total of 406 benthic foraminifera were collected from the five samples (mean-M-: 81 individuals picked per sample), belonging to 32 genera and 45 species. Suborden Rotaliina is dominant in all samples (55.71\%-75.76\%; M: 66.36\%), with miliolids as main secondary component (18.18\%-41.43\%; M: $29.77 \%$ ). This distribution is typical of normal marine lagoons, estuarine channels or normal marine marshes [8,14]. The most abundant species are Ammonia beccarii (3.03\%-38.46\%; M: 18.97\%), Triloculina trigonula (5.13\%-18.18\%; M: 12.59\%), Quinqueloculina seminulum (0-10\%; M: 6.05\%), Quinqueloculina vulgaris (0-10\%; M: 6.05\%) and Ammonia tepida (0-30.03\%; M: 6\%). Sixteen benthic species are present in an isolated sample, such as A. tepida (sample 1: $30.03 \%$ ). Density of these microorganisms is low to very low $(<1$ individual/gram-4 individuals/gram), with a very low number of individuals in the innermost areas, at the confluence with a tributary channel (sample 1). In other estuaries, this scarcity or even the absent of this group has been observed in the main channels subjected to a strong erosion of the bottom or high hydrodynamic gradients [15]. Diversity is low in most samples (13-19 species), with a remarkable increase in sample 4 (34 species) (Table 1).

Table 1: Sixteen benthic species present in different sample

\begin{tabular}{|c|c|c|c|c|c|c|c|c|c|c|c|}
\hline \multirow{2}{*}{ Suborden } & \multirow{2}{*}{$\begin{array}{l}\text { Species/ } \\
\text { Samples }\end{array}$} & \multicolumn{2}{|l|}{1} & \multicolumn{2}{|c|}{2} & \multicolumn{2}{|c|}{3} & \multicolumn{2}{|c|}{4} & \multicolumn{2}{|l|}{5} \\
\hline & & Individuals & $\%$ & Individuals & $\%$ & Individuals & $\%$ & Individuals & $\%$ & Individuals & $\%$ \\
\hline \multirow{3}{*}{ Lagenina } & Lagena costata & & & & & & & 1 & 0.64 & & \\
\hline & Lagena sp. & & & & & & & 1 & 0.64 & & \\
\hline & $\begin{array}{c}\text { Pseudonodosaria } \\
\text { aequalis }\end{array}$ & & & & & & & 1 & 0.64 & & \\
\hline \multirow{7}{*}{ Miliolina } & Adelosina laevigata & & & & & & & 5 & 3.21 & & \\
\hline & Adelosina pulchella & & & & & & & 2 & 1.28 & 5 & 6.4 \\
\hline & $\begin{array}{l}\text { Miliolinella } \\
\text { circularis }\end{array}$ & & & & & & & 7 & 4.49 & & \\
\hline & $\begin{array}{l}\text { Quinqueloculina } \\
\text { seminulum }\end{array}$ & & & 7 & 10 & 6 & 8.7 & 8 & 5.13 & 5 & 6.4 \\
\hline & $\begin{array}{c}\text { Quinqueloculina } \\
\text { vulgaris }\end{array}$ & & & 7 & 10 & 6 & 8.7 & 8 & 5.13 & 5 & 6.4 \\
\hline & Triloculina oblonga & & & 3 & 4.29 & & & 9 & 5.77 & & \\
\hline & $\begin{array}{c}\text { Triloculina } \\
\text { trigonula }\end{array}$ & 6 & 18.18 & 12 & 17.14 & 8 & 11.59 .59 & 17 & 10.9 .9 & 4 & 5.13 \\
\hline
\end{tabular}


Oceanography \& Fisheries Open access Journal

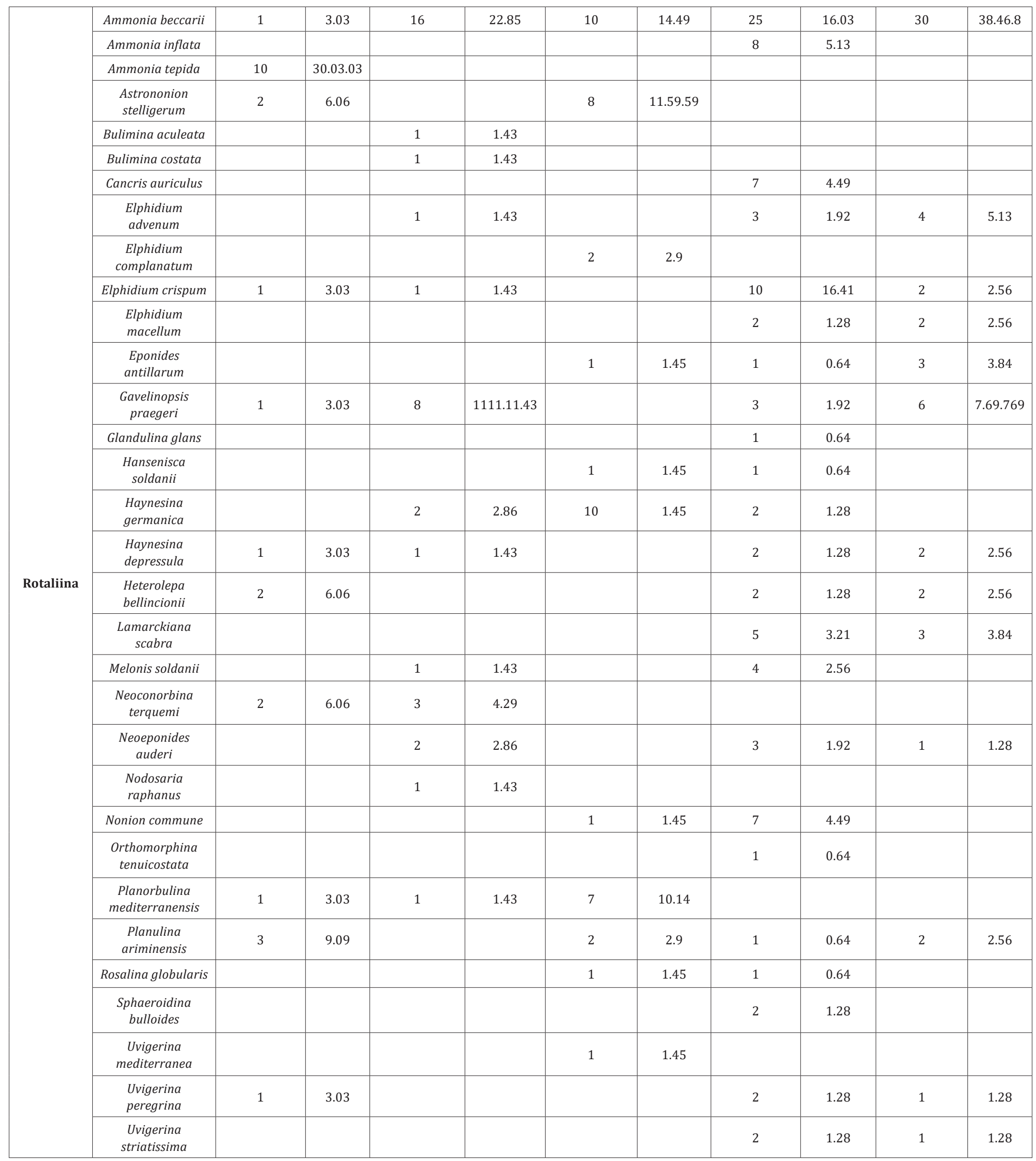




\section{Oceanography \& Fisheries Open access Journal}

\begin{tabular}{|c|c|c|c|c|c|c|c|c|c|c|}
\hline \multirow{3}{*}{ Textulariina } & Entzia macrescens & & & & & 1 & 1.45 & & & \\
\hline & $\begin{array}{c}\text { Textularia } \\
\text { sagittula }\end{array}$ & & & 1 & 1.43 & & & & & \\
\hline & $\begin{array}{l}\text { Trochammina } \\
\text { inflata }\end{array}$ & 2 & 6.06 & 1 & 1.43 & 4 & 5.8 & 2 & 1.28 & \\
\hline \multicolumn{2}{|c|}{ Number of Individuals } & \multicolumn{2}{|c|}{33} & \multicolumn{2}{|c|}{70} & \multicolumn{2}{|c|}{69} & \multicolumn{2}{|c|}{156} & 78 \\
\hline \multicolumn{2}{|c|}{ Number of Species } & \multicolumn{2}{|c|}{13} & \multicolumn{2}{|c|}{19} & \multicolumn{2}{|c|}{16} & \multicolumn{2}{|c|}{34} & 17 \\
\hline \multicolumn{2}{|c|}{ P/B Index (\%) } & \multicolumn{2}{|c|}{29.2} & \multicolumn{2}{|c|}{27.7} & \multicolumn{2}{|c|}{28.2} & \multicolumn{2}{|c|}{20.3} & 17.5 \\
\hline \multicolumn{2}{|c|}{ Suborden Lagenina (\%) } & \multicolumn{2}{|c|}{0} & \multicolumn{2}{|c|}{0} & \multicolumn{2}{|c|}{0} & \multicolumn{2}{|c|}{1.92} & 0 \\
\hline \multicolumn{2}{|c|}{ Suborden Miliolina (\%) } & \multicolumn{2}{|c|}{18.18} & \multicolumn{2}{|c|}{41.43} & \multicolumn{2}{|c|}{28.99} & \multicolumn{2}{|c|}{35.91} & 24.33 \\
\hline \multicolumn{2}{|c|}{ Suborden Rotaliina (\%) } & \multicolumn{2}{|c|}{75.76} & \multicolumn{2}{|c|}{55.71} & \multicolumn{2}{|c|}{63.76} & \multicolumn{2}{|c|}{60.89} & 75.67 \\
\hline \multicolumn{2}{|c|}{ Suborden Textulariina (\%) } & \multicolumn{2}{|c|}{6.06} & & & & & & & 0 \\
\hline
\end{tabular}

Abundance (in \%), density and diversity of benthic foraminifera and evolution of the P/B index (in \%).

Planktonic foraminifera show a surprising pattern, since they gradually diminish towards the sea from sample. The highest values were found in the innermost sample (P/B: 29.2\%), while this group drops by $18 \%$ near the mouth. These microorganisms are introduced in suspension into the estuary by the tidal flows [16] and are deposited in the bottom when the speed of tidal currents decreases. The low values detected near the mouth may be due to a selective destruction of its thin shells in relation to the thicker shells of most benthic foraminifera, owing to the strong bottom currents of this area [17].

\section{Marine Estuary of the Guadalquivir River: Foramin- iferal Zonation}

Benthic foraminiferal distribution on the marine estuary of the Guadalquivir river allows to differentiate three zones. There is a gradation from the most internal sectors (Zone 1) to the mouth (Zone 3).

Zone 1 (Ammonia tepida zone): This zone is characterized by the lowest salinity $(<1 \mathrm{o} / \mathrm{oo})$ and $\mathrm{pH}$ values (7.3). In its silty-sandy bottom sediments, benthic foraminifera are very scarce and poorly diversified, with Ammonia tepida (30\%) and Trigonulina trigonula ( $>18 \%$ ) as main species. Ammonia tepida is a very common euryhaline species in estuarine environments, and can survive over a broad range of temperatures and seasonal regimes $[18,19]$. This zone presents the highest $\mathrm{P} / \mathrm{B}$ values $(>29 \%)$.

Zone 2 (Ammonia beccarii-Triloculina trigonula zone): This intermediate zone is characterized by very low salinities and an increase of the sandy contents in the bottom sediments. Ammonia beccarii replaces Ammonia tepida as dominant species, whereas the percentages of Triloculina trigonula decrease seaward. Ammonia beccarii is better adapted than Ammonia tepida to hydrodynamic stress conditions in estuarine environments, such as those present in the main channels near the mouths [7]. The joint presence of Trochammina inflata and Entzia macrescens indicates the erosion of adjacent salt marshes, where these species are dominant [20].

Zone 3 (Ammonia beccarii zone): The Guadalquivir river mouth presents both low densities $(<2$ individuals per gram) and diversity (17 species). The foraminiferal assemblage is dominated by Ammonia beccarii $(<38 \%)$, together with several species of Quinqueloculina ( $>19 \%$ ) and Elphidium (14\%). This assemblage is typical of shallow marine shelfs and the marine sectors of numerous estuaries [21,22]. Moreover, this energetic area shows the lower P/B values (17.5\%).

\section{Acknowledgment}

We thank Dr. Juan Antonio Morales (Universidad de Huelva, Spain) for his help in collecting the samples. This work has been carried out through the Project Study of the sediment characteristics and the recent sedimentary record of the Guadalquivir River Estuary (Port autority of Seville). Other funds have come from the Andalusian Government (groups RNM-238, RNM-276 AND RNM-293). It is a contribution to the Research Center in Historical, Cultural and Natural Heritage (CIPHCN) of the University of Huelva.

\section{References}

1. Sreenivasulu G, Praseetha BS, Daud NR, Varghese TI, Prakash TN, et al. (2019) Benthic foraminífera as potential ecological proxies for enviromental monitoring in coastal regions: A study on the Beypore estuary, Southwest coast of India. Marine Pollution Bulletin 138: 341-351.

2. Haller C, Smith CG, Hallock P, Hine AC, Osterman LE, et al. (2019) Distribution of Modern Salt-marsh Foraminifera from the Eastern Mississippi Sound, USA. Journal of Foraminiferal Research 49(1): 29-47.

3. Dimiza MD, Ravani A, Kapsimalis V, Panagiotopoulos IP, Skampa E, et al. (2019) Benthic foraminiferal assemblages in the severely polluted coastal environment of Drapetsona-Keratsini, Saronikos Gulf (Greece). Revue de Micropaléontologie 62(1): 33-44.

4. Parsaian M, Shokri MR, Pazooki J (2018) The response of benthic foraminifera to aquaculture and industrial pollution: A case study from the Northern Persian Gulf. Marine Pollution Bulletin 135: 682-693.

5. Martínez-Colón M, Hallock P, Green-Ruiz CR, Smoak JM (2018) Benthic foraminifera as bioindicators of potentially toxic element (PTE) pollution: Torrecillas lagoon (San Juan Bay Estuary), Puerto Rico. Ecological Indicators 89: 516-527.

6. Ruiz F, González-Regalado ML, Morales JA (1996) Distribución y ecología de los foraminíferos y ostrácodos actuales del estuario mesomareal del río Guadiana (SO España). Geobios 29(5): 513-528.

7. González-Regalado ML, Ruiz F, Morales JA (1998) Relación entre submedios sedimentarios y los foraminíferos bentónicos del subsistema Carreras (Río Guadiana, SO de España). Boletín de la Real Sociedad Española de Historia Natural (Sección Geología) 94(1-2): 65-76. 
8. González-Regalado ML, Ruiz F, Baceta JI, González-Regalado E, Muñoz JM (2001) Total benthic foraminifera assemblages in the southwestern Spanish estuaries. Geobios 34(1): 39-51.

9. Vanney JR (1970) L'hydrologie du Bas Guadalquivir. In: Consejo Superior de Investigaciones Científicas, Spain, pp. 175

10. Menanteau L (1979) Les Marismas du Guadalquivir. Example de transformation d'un pausage alluvial au cours du Quaternaire récent. Thèse 3er cycle, Université Paris-Sorbonne, pp. 323.

11. Borrego J, Morales JA, Pendón JG (1993) Elementos morfodinámicos responsables de la evolución reciente del estuario bajo del río Guadiana (Huelva). Geogaceta 11: 86-89.

12. Bodelón OG, Bernués M, Baltanás A, Montes C (1994) Conductividad y salinidad en los ecosistemas acuáticos del Parque Nacional de Doñana. Limnetica 10(2): 27-31.

13. Baldó F, Cuesta JA, Fernández-Delgado C, Drake P (2005) Efecto de la regulación del caudal del Río Guadalquivir sobre las características fisicoquímicas del agua y la macrofauna acuática de su estuario. Ciencias Marinas 31(3): 467-476.

14. Murray J (2006) Ecology and applications of benthic foraminifera. In: Cambridge University Press, US, pp. 426

15. Bonetti C, Eichler BB (1997) Benthic foraminifera and thecamoebians as indicators of river/sea gradientes in the estuarine zone of Itapitangui River-Cananéia/SP, Brazil. Anais da Academia Brasileira de Ciências 69(4): 544-563.
16. Wang P, Murray JW (1983) The use of foraminifera as indicators of tidal effects in estuarine deposits. Marine Geology 51(3-4): 239-250.

17. Costa S, Gutiérrez-Mas JM, Morales JA (2009) Establecimiento del régimen de flujo en estuario del Guadalquivir, mediante el análisis de formas de fondo con sonda multihaz. Revista de la Sociedad Geológica de España 22(1-2): 23-42.

18. Pascal P, Dupuy C, Richard P, Niquil N (2008) Bacterivory in the common foraminifer Ammonia tepida: Isotope tracer experiment and the controlling factors. Journal of Experimental Marine Biology and Ecology 359: 55-61.

19. Wu J, Liu C, Fürsich FT, Yang T, Yin J (2015) Foramifera as environmental indicators and qunatitative salinity reconstructions in the Pearl river estuary, southern China. Journal of Foraminiferal Research 45(3): 205-219.

20. Camacho SG, Moura DMJ, Connor S, Scott DB, Boski T (2015) Taxonomy, ecology and biogeographical trends of dominant benthic foraminifera species from an Atlantic-Mediterranean estuary (the Guadiana, southeast Portugal). Palaeontologia Electronica 18.1(17A): 1-27.

21. Mendes I, González R, Dias JMA, Lobo F, Martins V (2004) Factors influencing recent benthic foraminifera distribution on the Guadiana shelf (Southwestern Iberia). Marine Micropaleontology 51(1-2): 171-192.

22. Kumar DN, Ganesh B, Karudu TK, Rao MJ (2012) A record on benthic foraminiferal abundance and distribution in Gosthani estuary, Bheemunipatnam, Andhra Pradesh. Indian Journal of Geo-Marine Sciences 41(5): 425-429.

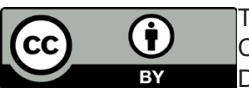

This work is licensed under Creative Commons Attribution 4.0 Licens DOI: 10.19080/OFOAJ.2019.09.555758 